кандидат юридических наук, заведующая кафедрой управления и права Института развития образования

Сахалинской области

\section{ПРАВО НА ОБРАЗОВАНИЕ В РОССИЙСКОЙ ФЕДЕРАЦИИ: КОНСТИТУЦИОННЫЙ АСПЕКТ}

Аннотация:

В статье представлен анализ конституционноправового закрепления права на образование в Российской Федерации, рассмотрены нормы международных правовых актов, устанавливающих это право. Конституционно-правовой анализ права на образование, отнесенного к группе основных социальных прав и свобод человека, позволил выделить ряд его особенностей, а именно производность от права на жизнь, возможность представления как в объективном, так и в субъективном смысле, вариативность объема и содержания. Являясь сложным по своему составу, конституционное право на образование представлено перечнем относительно самостоятельных прав и свобод и в определенных случаях может рассматриваться одновременно и как конституционное право, и как конституционная обязанность по получению образования. Основными требованиями, предъявляемыми к гарантиям права на образование, должны быть их действенность и эффективность, поскольку они ориентированы на обеспечение реализации этого права каждым человеком. Законодательное закрепление и выполнение на практике эффективных гарантий права на образование в Российской Федерации являются одними из основных целей государственной политики в области образования.

Ключевые слова:

право на образование, Конституция Российской Федерации, социальные права и свободы, бесплатность и доступность образования, конституционное право, конституционная обязанность.
PhD in Law Head of the Management and Law Department, Institute for Education Development of

Sakhalin Region

\section{THE RIGHT TO EDUCATION IN THE RUSSIAN FEDERATION: THE CONSTITUTIONAL ASPECT}

Summary:

The article analyzes the constitutional and legal consolidation of the right to education in the Russian Federation. The standards of international legal acts establishing this right are examined. The constitutional and legal analysis of the right to education that is classified as the fundamental social rights and freedoms of human made it possible to identify its features. First of all, it originates from the right to life. Second of all, it can be objectively and subjectively interpreted. Moreover, it is characterized by a variety of scope and content. Having complex structure, the constitutional right to education is represented by a list of relatively independent rights and freedoms, and in certain cases, it may be considered both as a constitutional right and as a constitutional obligation to get education. The basic requirements for the guarantees of the right to education must include their efficiency and effectiveness since they are aimed at ensuring the realization of this right by everyone. Legislative consolidation and implementation of effective guarantees of the right to education in practice is one of the main goals of state policy in education in the Russian Federation.

Модернизация системы образования рассматривается как необходимый и определяющий фрактор социального и экономического развития российского государства. Это объясняется тем, что наивысшую ценность и основной капитал в современном обществе, согласно действующей Конституции, представляет человек, обладающий способностями осуществлять поиск и осваивать новые знания, принимать обдуманные и нестандартные решения.

Международные стандарты в области прав человека способствуют формированию общего образовательного пространства и общих направлений развития современного образовательного права.

Международными правовыми актами право на образование отнесено к фундаментальным естественным основным правам человека. Такой подход в понимании права на образование представлен во Всеобщей декларации прав человека, в Конвенции о борьбе с дискриминацией в области образования, Международном пакте об экономических, социальных и культурных правах, Конвенции о правах ребенка, Европейской конвенции о защите прав человека и основных свобод. ЮНЕСКО рекомендовано право на образование рассматривать в качестве одного из элементов права на жизнь, права на развитие. Право на образование является составной частью права на получение непрерывного образования, реализация которого предполагается на протяжении всей жизни человека.

В ст. 26 Всеобщей декларации прав человека 1948 г. не только закреплено право каждого человека на образование, но и заявляется о необходимости бесплатного и обязательного начального 
образования, бесплатности общего образования, общедоступности технического и профессионального образования, доступности высшего образования исходя из способностей каждого [1, с. 8].

Международный пакт об экономических, социальных и культурных правах 1966 г. в ст. 13 также устанавливает возможность каждого человека на получение образования, декларируя, что полное осуществление этого права возможно: при обязательном и бесплатном начальном образовании; доступном среднем образовании, включая профессионально-техническое среднее образование; высшем образовании, доступном для каждого на основе способностей; постепенном введении бесплатного среднего и высшего образования; активном развитии сети школ всех ступеней; удовлетворительной системе стипендий и постоянном улучшении материальных условий преподавательского персонала [2]. Таким образом, Пактом предусматривается разный объем права на образование в зависимости от ступеней обучения, но конкретно детализируются цели образования. Согласно Пакту, образование должно быть ориентировано на полное развитие личности человека, уважение его достоинства и должно способствовать укреплению уважения к правам человека и основным свободам, обеспечить возможность каждому быть полезным участником свободного общества и содействовать развитию взаимопонимания, терпимости и дружбы между нациями и народностями, религиями, содействовать работе Организации Объединенных Наций по поддержанию мира [3].

Европейской конвенцией о защите прав человека и основных свобод устанавливаются запрет на отказ кому-либо в реализации его права на образование, запрет на любые виды дискриминации в рамках реализации права на образование [4].

Конвенция о правах ребенка 1989 г. также является одним из базовых документов, устанавливающих международные стандарты права несовершеннолетнего на образование. В ст. 28 Конвенции государствами-участниками закреплено право каждого ребенка на образование на основе равных возможностей. Для обеспечения реализации этого права государства обязуются: создать условия для введения на своей территории бесплатного и обязательного начального образования; способствовать развитию разнообразных форм среднего образования, включая общее и профессиональное; обеспечить их общую доступность для каждого; гарантировать доступность высшего образования с учетом индивидуальных способностей; обеспечить информационную открытость в области образования и профессиональной подготовки детей; содействовать регулярному посещению занятий учащимися и снижению числа детей, не посещающих школу; гарантировать соблюдение права ребенка на уважение человеческого достоинства при поддержании школьной дисциплины [5].

Нормы, устанавливающие универсальные международные стандарты права на образование, закреплены и другими актами Организации Объединенных Наций, ее специализированных учреждений, иных региональных международных организаций. Однако конкретное содержание права на образование определяется внутренним законодательством каждого государства. Для большинства государств право на образование закрепляется на конституционном уровне правового регулирования, что, с одной стороны, отражает особую значимость, которая в государстве и обществе придается праву на образование, с другой - выступает дополнительной политико-правовой гарантией реализации этого права, дающей возможность его защиты в случае нарушения [6].

Так, согласно ст. 43 Конституции Российской Федерации право на образование имеет каждый. В основном законе понятие «каждый» определяет принадлежность этого права как гражданам РФ, так и иностранцам, лицам без гражданства вне зависимости от их принадлежности к определенной расе, национальности, от их полового признака, языка общения, происхождения, места жительства, религиозных и иных убеждений, участия в общественных организациях, возраста [7]. Реализация права на образование должна быть обеспечена каждому и не может ограничиваться состоянием здоровья, социальным, имущественным и должностным положением, наличием судимости. Конституционные основы реализации права на образование установлены в ст. 72 , согласно которой общие вопросы образования находятся в совместном ведении Российской Федерации и субъектов РФ, а также в ст. 114, в которой установлены полномочия Правительства РФ по обеспечению в Российской Федерации единой государственной политики в области образования.

Право на образование, отнесенное Конституцией РФ к основным правам и свободам человека, можно рассматривать в качестве производного от фундаментального права на жизнь. В науке право на образование относят к группе прав человека второго поколения. Эта группа объединяет такие социально-экономические и культурные права, как право на охрану здоровья, жилище, труд и отдых, социальное обеспечение, доступ к культурным ценностям и т. д.

В юридической науке право на образование может быть рассмотрено как в объективном, так и в субъективном смысле.

По мнению А.Н. Козырина, объективное право на образование, т. е. право на образование в объективном смысле, представляет собой совокупность правовых норм, необходимых для регулирования общественных отношений, связанных с получением образования. Субъективное образовательное право (право на образование в субъективном смысле) - это гарантированные государством и международным правом фрактические возможности индивида, заключающиеся в 
обладании и пользовании необходимым объемом знаний, умений и навыков с целью повышения им своего образовательного и культурного уровня [8].

Право на образование, установленное Конституцией РФ и закрепленное основными международными актами по правам человека, представляет собой субъективное право. В своих исследованиях ученые-правоведы высказывают сходство во взглядах относительно содержания конституционного права на образование, делая акцент на его субъективный характер.

К примеру, содержание конституционного права на образование раскрывается Л.А. Дольниковой через обязательность процесса и результатов усвоения знаний, умений и навыков [9, с. 37]. Т.С. Румянцевой конституционное право на образование определяется как система норм, на основе которой регулируются общественные отношения, возникающие в процессе получения образования [10]. Особого внимания заслуживает определение С.С. Алексеева, который отмечает, что субъективные права индивида выражают не потенциальные, а его реальные возможности, которые должны быть закреплены в конституции и законах [11, с. 21]. Дополняя суждения С.С. Алексеева, О.Ю. Назарова утверждает, что право на образование следует представлять в качестве совокупности возможностей каждого человека на получение образования [12, с. 25]. Особой точки зрения придерживаются Я.Д. Стешенко и С.Н. Степанько, относя право ребенка на образование к группе культурных прав человека и рассматривая его как особую разновидность международно признанного и одновременно с этим имеющего конституционную форму закрепления основного права индивида [13, с. 57].

Обобщая позиции ученых, можно утверждать, что право на образование является особо значимым социальным правом человека, создающим необходимые предпосылки для развития личности, оказывающим влияние на состояние общества в целом, находясь во взаимосвязи с иными политическими, экономическими и социальными правами и свободами.

Каждый человек приобретает право на образование естественным способом, то есть на основании фракта своего рождения и благодаря тому, что человеку по его природе присущи развитие личности, накопление опыта и получение новых знаний, желание творить и потребность передавать все накопленное молодому поколению. Образование дает возможность и создает условия для полноценной жизни человека в обществе.

Основные права, включая право на образование, принадлежат человеку изначально и не зависят от воли государства. В праве на получение образования не может быть отказано никому. Государство гарантирует и обеспечивает реализацию этого права. Являясь основным правом человека, право на образование не может передаваться другим лицам, отчуждаться в какой бы то ни было форме или быть дарованным. Кроме того, сам человек не может добровольно отказаться от права на получение образования в силу обязательности основного общего образования в Российской Федерации и в соответствии с международными стандартами. Реализация права на образование способствует социализации человека в современном обществе.

Современное понимание права на образование предусматривает свободу образования, которая включает в себя возможности по получению образования всеми желающими с учетом их религиозных или идеологических убеждений; предполагает свободу выбора организации, осуществляющей образовательную деятельность, свободу выбора программы обучения, педагогических и академических методов, способов и форм обучения, языка обучения, свободу на получение образования различных уровней и др.

За последние пять лет в Российской Федерации проведена огромная работа по реформированию образовательного законодательства. Задача Федерального закона № 273-Ф3 от 29 декабря 2012 г. «Об образовании в Российской Федерации» - обеспечить реализацию конституционного права на образование, определить стратегию и основные направления развития российского образования.

Таким образом, конституционно-правовой аспект регулирования права на образование определяет принадлежность этого права к группе основных закрепленных конституционно социальных прав и свобод человека. Являясь сложным по своему составу, конституционное право на образование представлено перечнем относительно самостоятельных прав и свобод, производно от права на жизнь и в определенных случаях может рассматриваться одновременно и как конституционное право, и как конституционная обязанность по получению образования.

\section{Ссылки:}

1. Всеобщая декларация прав человека от 10 декабря 1948 г. М., 2003. 10 с.

2. Международный пакт об экономических, социальных и культурных правах от 16 декабря 1966 г. // Бюллетень Верховного суда РФ. 1994. № 12.

3. Там же.

4. Конвенция о защите прав человека и основных свобод от 4 ноября 1950 г. // Собрание законодательства РФ. 2001. № 2. Ст. 163 . 
5. Конвенция о правах ребенка 1989 г. // Ведомости Съезда народных депутатов СССР и Верховного Совета СССР. 1990. № 45. Ст. 955.

6. Glenn Ch.L., Groof J. de. Educational Freedom and Accountability: An International Overview [Электронный ресурс]. URL: https://sites.hks.harvard.edu/pepg/PDF/events/WNConfPDF/GlennDeGroofWN02-18.pdf (дата обращения: 07.08.2017).

7. Конституция Российской Федерации // Собрание законодательства РФ. 2014. № 31. Ст. 4398.

8. Козырин А.Н. Статья 5. Право на образование. Государственные гарантии реализации права на образование в Российской Федерации [Электронный ресурс] // Реализация положений Федерального закона от 29 дек. 2012 г. № 273Ф3 «Об образовании в Российской Федерации». URL: http://www.lexed.ru/praktika/realizatsiya-273-fz/detail.php?ELEMENT_ID=2460 (дата обращения: 26.06.2017).

9. Дольникова Л.А. Конституционное право на образование советских граждан : дис. ... канд. юрид. наук. Саратов, 1984.

10. Румянцева Т.С. Конституционное право на образование в социалистических странах : дис. ... канд. юрид. наук. М., 1984.

11. Алексеев С.С. Теория права. М., 1995. 320 с.

12. Назарова О.Ю. О природе права на образование // Вестник Томского государственного педагогического университета. 1999. № 3 (13). Серия: Гуманитарные науки (правоведение). С. 24-25.

13. Стешенко Я.Д., Степанько С.Н. Право ребенка на образование и защита прав учащихся общеобразовательных учреждений // Юный ученый. 2015. № 1. С. 56-58.

\section{References:}

Alekseev, SS 1995, The theory of law, Moscow, 320 p., (in Russian).

Dolnikova, LA 1984, The constitutional right to education of Soviet citizens, PhD thesis, Saratov, (in Russian).

Glenn, ChL \& Groof, Jde 2017, Educational Freedom and Accountability: An International Overview, viewed 07 August 2017, $<$ https://sites.hks.harvard.edu/pepg/PDF/events/WNConfPDF/GlennDeGroofWN02-18.pdf>.

'International Covenant on Economic, Social and Cultural Rights of December 16, 1966' 1994, Byulleten' Verkhovnogo suda $R F$, no. 12, (in Russian).

Kozyrin, AN 2017, 'Article 5. Right to education. State guarantees to implement the right to education in the Russian Federation', Realizatsiya polozheniy Federal'nogo zakona ot 29 dek. 2012 g. № 273-FZ "Ob obrazovanii v Rossiyskoy Federatsii", viewed 26 June 2017, <http://www.lexed.ru/praktika/realizatsiya-273-fz/detail.php?ELEMENT_ID=2460>, (in Russian).

Nazarova, OYu 1999, 'The nature of the right to education', Vestnik Tomskogo gosudarstvennogo pedagogicheskogo universiteta. 1999. № 3 (13). Seriya: Gumanitarnyye nauki (pravovedeniye), pp. 24-25, (in Russian).

Rumyantseva, TS 1984, The constitutional right to education in socialist countries, PhD thesis, Moscow, (in Russian).

Steshenko, YaD \& Stepanko, SN 2015, 'The right of the child to education and protection of the rights of the secondary school students', Yunyy uchenyy, no. 1, pp. 56-58, (in Russian).

'The Constitution of the Russian Federation' 2014, Sobraniye zakonodatel'stva RF, no. 31, Art. 4398, (in Russian).

'The Convention for the Protection of Human Rights and Fundamental Freedoms of November 04, 1950' 2011, Sobraniye zakonodatel'stva RF, no. 2, Art. 163, (in Russian).

'The Convention on the Rights of the Child of 1989' 1990, Vedomosti S"yezda narodnykh deputatov SSSR i Verkhovnogo Soveta SSSR, no. 45, Art. 955, (in Russian).

The Universal Declaration of Human Rights of December 10, 1948 2003, Moscow, 10 p., (in Russian). 